\title{
Corrigendum: Different Preclimacteric Events in Apple Cultivars with Modified Ripening Physiology
}

\section{OPEN ACCESS}

Edited and reviewed by: Claudio Bonghi, Università degli Studi di Padova, Italy

${ }^{*}$ Correspondence: Haya Friedman hayafr@agri.gov.il

Specialty section: This article was submitted to Plant Breeding, a section of the journal

Frontiers in Plant Science

Received: 17 September 2017 Accepted: 02 October 2017 Published: 16 October 2017

Citation:

Singh V, Weksler $A$ and Friedman $H$ (2017) Corrigendum: Different Preclimacteric Events in Apple Cultivars with Modified Ripening Physiology. Front. Plant Sci. 8:1784. doi: 10.3389/fp/s.2017.01784

\section{Vikram Singh, Asya Weksler and Haya Friedman*}

Department of Postharvest Science of Fresh Produce, Agricultural Research Organization, Volcani Center, Bet Dagan, Israel

Keywords: "anna", developmental regulators, ethylene biosynthesis, fruit development, MdFUL, system I/II, MdCNR, respiration

\section{A corrigendum on}

Different Preclimacteric Events in Apple Cultivars with Modified Ripening Physiology by Singh, V., Weksler, A., and Friedman, H. (2017). Front. Plant Sci. 8:1502. doi: 10.3389/fpls.2017. 01502

In the original article, Figure 8 and Supplementary Table 2 showed the number for MdRIN to be MDP0000326906. This is a mistake. The correct number is MDP0000366022.

The authors apologize for this error and state that this does not change the scientific conclusions of the article in any way.

Conflict of Interest Statement: The authors declare that the research was conducted in the absence of any commercial or financial relationships that could be construed as a potential conflict of interest.

Copyright $\odot 2017$ Singh, Weksler and Friedman. This is an open-access article distributed under the terms of the Creative Commons Attribution License (CC BY). The use, distribution or reproduction in other forums is permitted, provided the original author(s) or licensor are credited and that the original publication in this journal is cited, in accordance with accepted academic practice. No use, distribution or reproduction is permitted which does not comply with these terms. 